\title{
Holocaust in Kolozsvar: 1944
}

\author{
Gabriel Mayer \\ Correspondence: Gabriel Mayer, University of Hiafa- International School for Holocaust Studies, Israel
}

Received: May 20, 2014

doi:10.11114/ijsss.v2i3.419
Accepted: June 19, 2014

Available online: June 24, 2014

URL: http://dx.doi.org/10.11114/ijsss.v2i3.419

\begin{abstract}
Kolozsvar Holocaust: 1944 Kolozsvar during 1940-1945, and Cluj before and after, this city, the capital of Transylvania, was deeply affected by the Holocaust. Prior to WWII, it was a hub of cultural activity, led by a cadre of Jewish professionals, artists and academics, who wore their Magyarized identity with pride, and imagined this identity to be protective under the fascist, Nazi leaning governance of the Horthy regime. Operation Margharete, the Nazi invasion of Hungary, brought this to an end on March 19th, 1944 and on May3rd the Jewish population ghettoized and then deported on six trains from May 25th till June9th. Some evaded deportation, by escaping over the border to Romania, by utilizing false identities and hiding, or surviving in the Jewish Labor Force, and by 1945, started to return from the camps. This paper analyses the factors which were most in play during the Spring of 1944, offering detailed insight into how the population was tragically decimated by deportations to Auschwitz. In addition, the various means of escape and evasion, the behavior of the general population and the functions of the Jewish Council are scrutinized. Some new population statistics and models are introduced and shed light on elements previous historiography has omitted.
\end{abstract}

Keywords: Kolozsvar, Cluj, Operation Margharete, Auschwitz, population

\section{Introduction: Koloszvar, a Localized Case Study.}

The murder of the Hungarian Jews is a particularly tragic tale of the Holocaust. It is remarkable in that it occurred at the very last moment, even as the Soviet army was sweeping toward Hungary, when Romania had stopped deportation and offered a relative safe have, and especially so because no one thought that this could happen in Hungary. As will be discussed, this last remark turned out to be a key factor in the particular vulnerability of the Hungarian Jews. What the following paper will attempt is to analyze this very weakness and look at the local circumstance in Kolozsvar as seen in the light of the larger debacle the Hungarian Holocaust. From the start, and discussed in greater detail to follow, it is noted that the provinces- especially Northern Transylvania (Erdely)-experienced a near total annihilation of the Jewish population, while central Hungary, especially Budapest, was able to stave off almost total destruction. Thus we find local factors played out in context, and within, national and European Holocaust historiography, with differing outcomes largely dependent and determined by geography. The purpose of this work is to search for and analyze these local events and attempt to recover a little more information about the fate of the Jews of Kolozsvar. The key to dissecting the events as Koloszvar may be observed in a single document: a 1940 marriage certificate in Kolozsvar (Cluj).

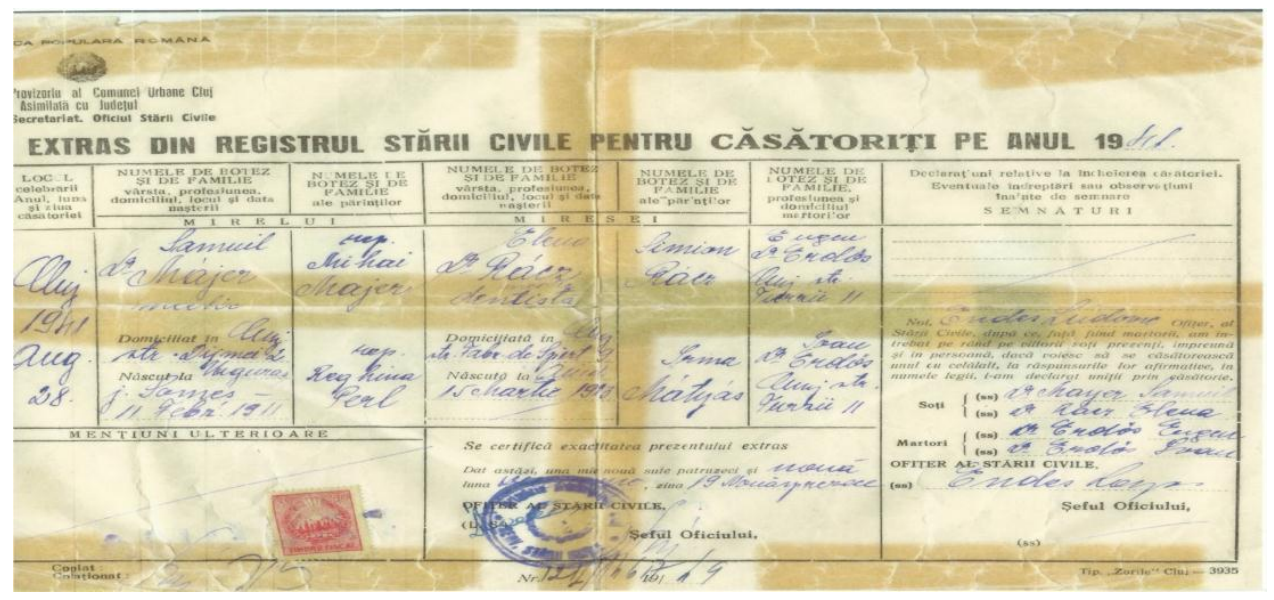

Figure 1. Courtesy of author 


\section{Marriage amid Chaos: Setting the Stage of Kolozsvar 1944}

Present in this document are four medical doctors, all graduates from Cluj Medical school, located in what was Romania in 1938; the bride related as a first cousin to the two witnesses (Drs. John and Eugen Erdos). Of note is that there were four additional Jewish classmates in the small graduating class of 1938, even under the numerous clausus rules. By 1944 the woman, Dr. Ilona Mayer would be escaping the ghetto with a ten-month-old child and walking to safety by crossing into Romania; the groom, Dr. Samuel Mayer inducted into the Hungarian Forced Labor Force, and the two brothers winding up in Auschwitz. How could such different fates befall four similar Jews living in the city of Kolozsvar? (See figure 1)

\subsection{Events prior to 1944: The Jews of Kolozsvar}

The understanding of the catastrophic events, which transpired for the Jews of Kolozsvar in the spring of 1944, is draped across two time-lines. A general and several decades long perspective points to an assimilated Jewry identifying itself in a Magyarized fashion and clinging to this notion despite warning signals, because of a maintained sense of security, which may seem odd in hindsight, but was easily understandable in a contemporaneous setting. The second, much shorter, brutal, and fatefully murderous turn of events rolled out during nine weeks from March 19 -May 25, when the first trains started to depart to Auschwitz.

As can be seen in Hungarian Jewish history, a much heralded and unparalleled set of events- assimilation- propelled the Jews of Hungary to economic and social success, which, even after Trianon and Romania's annexation of Transylvania remained as a bedrock of identity for the Koloszvar Jews, much as it did in the rest of Northern Transylvania. According to the 1940 Second Vienna award Transylvania (and Kolozsvar) reverted to Hungary and by 1941, the time of promulgation of the Third Jewish Laws, the fate of Kolozsvar's Jews was in the hands of the Hungarian political system.

It is a fact that murderous rampages took place in Transylvania as early as July 1941- Kaments-Podolski- but despite wide knowledge of these massacres and brutal social and economic sanctions, the city of Kolozsvar was insulated from the most severe actions seen elsewhere. "But as harsh as these measures were, they did not shake the basic confidence of Hungarian Jews, and especially the assimilated ones, that they were not in physical danger".(Braham 1981, 199) Indeed, records show that social life, schooling, intellectual functions such as art and concerts continued well into early 1944 (Carmilly-Weinbereger 1970, 112-116). Furthermore, when the tide of war began to turn on the Eastern Front, the Horthy government started to relax some of the anti Jewish measures during 1943 in what has been described as the thaw of 1943(Cohen 1986, 33-51)

By 1944 refugees and escapees from the East had arrived in Transylvania, told the populace of mass murders and catastrophes, but on the other hand even they were in disbelief when strolling through town: "They had not expected a place where there was no "yellow star" and Jews could walk about freely without fear, and could go on trips." (Cohen 1986, 45). It is on this background that Kolozsvar commenced the year of 1944.

While there were some indications of a hardening of Nazi attitude toward Hungarian politics (Horthy and Kallay had drawn their suspicion in 1943) no one predicted the sudden German invasion on March 19,1944- Operation Margharete was launched while Horthy was on a state visit to Hitler, his return held back for this very reason.(Braham 1994, 369)

\subsection{Nazi Order in Hungary: The Beginning of the End}

Knowing, then, the immediate sequence of events, we turn our examination to the executive system- Gendarmerie, police, local government, and newly formed Hungarian ministerial appointments of Endre and Baky - to look at how the Jews were handled toward destruction.

While Eichmann's organization and the 200 or so expert members of his specialized Sonderkommandos, brought in specifically to address the Final Solution in Hungary, stand out, what actually took place on the ground level is clearly attributable to Hungarian efforts and they were well prepared. The backbone of Hungarian security forces was the Gendarmerie. Initially formed after WWI as part of a Home Guard force during a time when standing armed forces were limited by treaty, these troops were well trained and over decades developed into a force to be reckoned with. Working with local police in the provinces, the Gendarmerie forces were manned by a cadre of hardened, vicious and especially loyal men, whose dedication was assured by a policy that they received regional appointments away from their home, province or town, thus ensuring that local passions would not sway them. These units were divided into ten regional command areas, or districts, and Kolozsvar was located in Gendarmerie District IX. 
The Gendarmerie was a highly trained, elite, paramilitary force that employed military ranks and was under military discipline. Regular Gendarmes were hand-picked volunteers, who underwent a full year of college-level training in law and administrative procedures. They wore a distinctive uniform, and a special hat with a chin strap anc a large plume of feathers that cascaded off to the left side. Armament consisted of a Mannlicher rifle mounting an unusually long bayonet. The 10 Gendarmerie district commands and their commanders in early 1944 were as follows

\begin{tabular}{|lll|}
\hline I & Gend. Dist. Cmd, - Budapest & Cal. Lénárd Torzsay \\
II & Gend. Dist. Cond. - Székesfehérvár & Col. József Zirczy \\
III & Gend. Dist. Cmd. - Szombathely & Col. Vilmos Poltáry \\
IV & Gend. Dist. Cmd. - Pécs & Col. László Perey \\
V & Gend. Dist. Cmd. - Szeged & Col. Vilmos Sellyey \\
VI $\quad$ Gend, Dist. Cmd. - Debrecen & Col. Artúr Sasady \\
VII Gend. Dist. Cmd. - Miskolc & Col. József Bátky \\
VIII Gend. Dist. Cmd. - Kassa & Cal. Gyözö Tölgyesy \\
IX Gend. Dist. Cmd. - Kolozsvár & Col. Ferenc Vattay \\
X Gend. Dist. Cmd. - Marosvásárhely & Cal. Aladár Pintér \\
\hline
\end{tabular}

Table 1. Gendarmeie Districts (Courtesy of Hungarian Gendarmerie Website)

The Nazi hammer fell within hours of the invasion: March 19, 1944. (Cohen 1984). During the first week the Jewish leadership was assured of safety as long as order prevailed, though on March 28 150-200 targeted Jews were suddenly arrested. The order to form a Jewish Council-Judenrat- was promulgated sometime at the end of March and about this time an increasing series of appropriations (of property) and deprivation followed. The head of the Kolozsvar Jewish Council was Dr. Joseph Fischer (Rezso Kasztner's father in law) and while a very active Zionist, indeed as were many Jews in Kolozsvar, he advised the populace to follow directions, perhaps believing the story of an impending resettlement (in early May he was visited by Kasztner, who, having received permission by Eichmann for the trip, was aware of the Vrba-Wetzler Report detailing deportation, but by accounts, did not share this information). Of note here, is that the entire Jewish leadership in Budapest was aware of the report, but chose to keep it under cover(Molnar 2002). Basically impotent to act, the Judenrat observed a series of measures: closure of all Jewish shops, ordered on March22nd, order to wear Yellow Star issued April5th, turning over of housing ordered on April $12^{\text {th }}$ and finally the order for ghettoization, enacted on April $28^{\text {th }}$ and carried out in Kolozsvar -starting at 5AM, one hour before sunrise- on May $3^{\text {rd }}$.(Löwy and Schvarcz 1998, 100-123)

The deportation of the Jews of Kolozsvar commenced on May $25^{\text {th }}$ and in six trains, the last one on June $9^{\text {th }}$ all were transported to Auschwitz. (See table 2 for deportation and trains). (Braham 1981)

Table 2. Deportations ( tabulated by author from the "Leo Glaser" list)

\section{TRAINS DEPORTING KOLOZSVAR JEWS TO}

AUSCHWITTZ

\begin{tabular}{|l|c|r|r|}
\hline DATE & $\begin{array}{l}\text { TRAIN } \\
\text { N\# }\end{array}$ & $\begin{array}{l}\text { PEOPLE } \\
\text { ABOARD }\end{array}$ & $\begin{array}{l}\text { ARRIVAL TO } \\
\text { AUSCHWITZ }\end{array}$ \\
\hline MAY 25 & 41 & $\mathbf{3 1 3 0}$ & MAY 27 \\
\hline MAY 29 & 56 & $\mathbf{3 4 1 7}$ & MAY 31 \\
\hline MAY 31 & 64 & $\mathbf{3 2 7 0}$ & JUNE 2 \\
\hline JUNE 2 & 73 & $\mathbf{3 1 0 0}$ & JUNE 4 \\
\hline JUNE 8 & 89 & $\mathbf{1 7 8 4}$ & JUNE 10 \\
\hline JUNE 9 & 91 & $\mathbf{1 4 4 7}$ & JUNE 11 \\
\hline \multicolumn{4}{|c|}{ TOTAL: $\mathbf{1 6 1 4 8}$} \\
\hline
\end{tabular}




\section{Fate, Fortune and Luck: Various Methods of Escape}

A discussion and analysis of these events is quite complex and must be undertaken in the light of contemporaneous events, rather than historical hindsight, which is often full of judgments and recriminations. What follows is a look at some of the factors affecting individual fate, not necessarily a result of personal agency, but most usually from a combination of fortune and, at times, quick action. As an example of the latter are the few who managed in the last days or hours to cross the border to Romania. While the numbers are small and will never be precisely known, there are accounts of walking on foot, even during the last hours, and certainly, some were able to plan this form of evasion weeks beforehand. Included in this category are those provided special dispensation and travel permits by the authorities -Dr. Erno Marton for example, politically connected individuals and a group of religious leaders, all fall in this group. In addition young members of the Halutz and Zionist movements were passing out forged documents starting in early 1944, becoming aware of these eventualities as a result of their excellent contacts and networks. The Hungarian Forced Labor Service was a significant factor, as it turns out, for avoidance of deportation and, in retrospect, for survival for those who managed to return. We don't have precise numbers for Kolozsvar, but the 1946 World Jewish Congress attempted an accounting for this group of individuals and estimated between 50,000-70,000 casualties out of perhaps 90,000- the numbers inclusive for all Hungarian Jews(Lőwy and Schvarcz 1998, 100-123). Yet it is significant that, in the end, this may have accounted for a number of Kolozsvar survivors(Gidó 2010, 61-63),(Braham 1977). An additional consideration: while the third set of Jewish Laws produced classifications of Jews quite similar to the Nuremberg laws, the role of apostasy and conversion as a means of evasion and survival should not be overlooked and may, in the future, produce some more precise figures.

Over the years, scholarship of historiography, personal accounts, biographies and testimonies have often been embroiled in a series of recrimination and accusation, perhaps best exemplified by the Rezso Kasztner saga and the accounts of Rudolf Vrba(Vrba and Bestic 1964).On May 22, 1994 the United States Holocaust Memorial Institute (USHMM) presented a conference on the Holocaust in Hungary- 50 years after which resulted in the publication of "The Nazis Last Victims" (Braham, Miller, and United States Holocaust Memorial Museum. 1998) and in this short volume some contentious opinions ranging from Yehuda Bauer to Rudolf Vrba and Asher Cohen illustrate the range of arguments. In 2014, seventy years after, it may be more desirable to represent history from various viewpoints, based on multiple accounts, often conflicting, without ascribing judgments, in a manner suitable for future research and scholarship. Rudolf Vrba, passed in 2006, and perhaps just a handful remain from these times. This report attempts to continue a dialogue, highlighted through multiple accounts, of our current understanding, carefully avoiding judgment.

The following factors are identified that demonstrate various responses and actions in Hungary, 1944. First, one is compelled to ask the following questions: why did they not fight or run? Is this tied to who knew what and when? Second, one must look critically at the role of the Jewish Councils (Judenrat) and their leadership issues. Third, many socioeconomic and special factors, along with privilege must be taken into account. These include the following components: religious groups, economic considerations, Zionism, special classes of privilege and a connection to manipulation and perpetration of massive fraud, the Jews of Sale issue, which is connected to money for blood and the Kasztner scandal, and finally, the participation of Orthodox Rabbis. Fourth, youth resistance and evasion can be seen through the Halutz and Zionist movements who forged and falsified documents for escape and rebellion. Fifth, evasion and escape to Budapest, to Romania and anywhere else was a continual process. Sixth, many went into hiding and relied on the help of those assisting them. Seventh, the Hungarian Forced Labor program was a major factor in spread of knowledge as well as influencing or deterring hiding and escape. Finally, eighth, there is the issue of apostasy and conversion, particularly because Hungarian Jewry was told conversion would allow for escape from deportation. How does this then skew the numbers?

\subsection{Who Knew What and When: Spreading Information}

A discussion of who knew what and when begins with Nazi planning. While a major factor for the March invasion was fear of loosing Hungary as an active member of the Tripartite alliance, once Kallay and Horthy started with overtures toward Allied countries, there is much evidence that implementing the Final Solution in Hungary was being planned months before March 19th and construction of special ramps at Auschwitz were being prepared at the start of 1944. This is well documented by a number of sources, most thoroughly in the Vrba-Wetzler Report(Braham, Miller, and United States Holocaust Memorial Museum. 1998) and in German records recovered after the war. Thus the argument that Horthy and the Hungarian government might easily have resisted the deportations does not hold water, notwithstanding the fact they were enthusiastic participants, and the intentional policy of non-interference well defined by Braham as "The Conspiracy of Silence" (Braham 1994, 805-848)What apparently perplexes historians and is the cause of much debate, is why the Jewish population did not rise up and whether, if informed by Jewish leaders, they might have resisted the deportations, and, furthermore, why did they not heed the ample warnings coming out of the East during the previous months, even years. To begin with, there was a small number, members of the Halutz and Zionist Youth 
movements, with better contacts, thus better informed, who actively debated resistance versus evasion and escape in dealing with the coming calamities.(Benshalom 2001, Cohen 1986) On the other hand, the very same reasons which caused the Nazis to commit to the decision to invade- the Hungarian government's communications with the Allies-was an excellent cause for Hungarian Jews to hold on to a belief that they would be protected(Cohen 1986) as regards to life and safety, despite the personal, financial and social misfortunes suffered. Asides from such historiographical details, one should not diminish the psychological state of the Jewish population- bewildered, frightened and impotentrendering them into a state of shock, they surely functioned under a stage of denial, well described in the medical literature as one of the five intellective stages when facing death.(Kübler-Ross 1975), (Kübler-Ross 1982).

\subsection{The Jewish Councils}

The order for the formation of the Jewish Council was delivered to the Jews of Budapest on March $20^{\text {th }}$ and in the following days, as they were organized, several meetings were held: March $20^{\text {th }}$-the first meeting-and March28th with Herman Krumey, Eichmann's representative, who instructed Jewish leaders to obey instructions and that no harm would befell them, and finally on March31st with Eichmann, who also delivered a similar message: follow orders and you will be safe (Molnar 2002, Munkácsi 1947)Exactly when these directives percolated to Kolozsvar are unclear, but Dr. Fischer appears to be mentioned as the president of the council by April5th when the order to wear the yellow star is promulgated. It has been noted that he was Rezso Kasztner's father in law and that he had contact with Kasztner during a period when Kasztner knew of the Vrba-Wetzler report.

While it is not known just how much information was exchanged between these various leaders in the Jewish community, it is evident that Kolozsvar Council had perhaps 30 days before the order to form the ghetto was given. Without conjuring obloquy, it appears that maintaining order(Bauman 1989, 23-25), as directed by Eichmann, would be an obvious choice in Kolozsvar, which, by this time was cut off from communications with Budapest as of the April $7^{\text {th }}$ decree forbidding travel, and an additional decree, interrupting all means of electronic communication also issued on the same, or next day. Further evidence demanding attention is the Nazi insistence on the representation, within the Jewish Council, of the various groups of Jewish organization, thus the Orthodox, Neologue, and Zionist and even Convert segments were accounted. This fact may lead to some conjectures regarding various special interest groups of people who managed to obtain special travel permits and partake evasive measures at the last moment. What is clear from historic records and subsequent interviews is the certainty that some members in leadership position knew in advance of the coming deportations(Bauman 1989, 23-25) and on or around April $16^{\text {th }}$ received word of the final destination. The three leading members of the Jewish Council, Dr. Erno Martin, Dr. Jozsef Fischer and Rabbi Mozes Weinberger were desperately seeking a solution and dispatched Marton to Bucharest, Romania for help and intercession(Vago 1966, 189). At the same time, in private, they were personally urging some people to flee to Romania. Dieter Wisliceny, Eichmann's aide made a visit to Kolozsvar sometime in April and again on May $2^{\text {nd }}$ to ensure that orders were being followed and by Weinberger's accounts (Lőwy and Löwy 2005, 171-175), keeping order in the general population, maximized the ability of individual flight. A few individuals, heading such advice chose to flee to the relative safety of Budapest- few in numbers, and often advised by the Zionist youth who provided travel papers(Carmilly-Weinbereger 1970), a few of them wound up with the controversial (and best known) Kasztner group. Still, one cannot escape the fact that economic and social advantages played a role and, later, would spawn bitter recriminations. On the other hand, was favoritism displayed for family members? That may be doubtful, taking, for instance, the case with Rabbi Weinberger, who at some point crossed the Romanian border, but whose parents Rosa and Solomon Weinberger were deported and perished at Auschwitz (Carmilly 1994).

\subsection{Blood for Goods: Massive Fraud and Eichmann}

For a discussion of special circumstances, in the case of those who managed to avoid deportation, one must begin with a starting point, which Yehuda Bauer has called a "massive fraud" perpetrated by Eichmann on the Jewish people(Carmilly 1994). Thus, the various schemes, such as "Blood for Goods" under Joel Brand, with no success, Kasztner's group on the train, and lesser-known efforts, which resulted in the occasional success by individuals and their families, should be viewed in this light. Eichmann's motivation was foremost the murder of Jews and this included any manipulation he could implement to further the objective.

\subsection{Zionist Movements}

The role of the Halutz and Zionist Youth movements in forming escape routes is best documented for residents of Budapest from where such efforts originated, and scant reporting accounts for Koloszvari citizens - whose main contacts were through Rezso Kasztner and Erno Marton. As early as 1943, once the situation in Romania became less critical for Jews, efforts were made to organize Tiyul expeditions designed to eventually reach Palestine. A combination of factors proved to be critical: the issuance of good false papers, which in part depended, on the other end, on organizations in Istanbul: The American Joint Distribution Committee (JDC), the newly formed (1944) American War 
Rescue Board (WRB), the Jewish Agency in Palestine and the International Red Cross who often served as the agent of funds transfers. Kolozsvar, along with Nagyvarad and Bekescsaba were the usual Tiyulim departure points from Transylvania and even after Nazi occupation there were a few instances of departures from Kolozsvar- where Dror-Habonim would account for the major efforts(Bauer 1994). Individual rescue efforts were not common in Kolozsvar, but are documented, as in the case of Dr. Rudolf Hainal- head of the internal medicine department in the Koloszvar Medical University - who kept several people hidden as patients on a ward for the duration of the occupation(Cohen 1986, 81-105).

\subsection{Religious Conversion as a Means for Escape}

Kolozsvar is $32 \mathrm{~km}$ from Torda, and there are even shorter routes to crossing the Romanian border, all within reasonable walking distance. During the three months from March-May the estimated crossings, not necessarily originating from Kolozsvar (but inclusive for Hungary), provided by several sources, account for 2,000 crossings aided by resistance organizations, another 5,000 individually- aided by the fact that most locals spoke Romanian well- and perhaps additional unreported numbers(Herzberger 2005, 345), (Lőwy and Lőwy 2005, 281).

The role of religious conversion is also to be considered a factor as far as survival and evasion, though the numbers may be difficult to pin down for the exact reason they worked and, furthermore, what figures are available tend to reflect the whole of Hungary and less so in the provinces, hence Kolozsvar. What we do know is that in 1941 a new Hungarian census was conducted and the initial printing of the polling sheets omitted the questions formulated through the third set of Jewish Laws- Act XV of Hungarian Parliament, effective August 8, 1941(Cohen 1986, 99)- which necessitated the addition of questions about grandparents and thus treated many converted Christians as Jews according to these "Nuremberg Laws style" of definition. Thus, while 62,000 admitted to being Jewish by ancestry, it is estimated that the actual numbers were over 100,000- noted in one section of the sampling (Magyar Statisztikai Szemle p.96 reported by Kovacs) This census was promulgated in the 1944/45 Magyar Statisztikai Szemle and, while some of the numbers differ widely from each other(Gidó 2010, 61), by examinations of the raw data, there is a general consensus of figures which counts approximately 786,555 Total Jews- made up from a totaling of Jews classified by religion and Jews who became classified by ethnicity as determined by one or more grandparent. However, other estimates and calculations place the total number of Jews reported -determined by including those defined by religion, those defined by ethnicity- and an estimated number of those not counted but who might have fit via either of the previous as 949,934, a number which agrees with other estimates which emerge(Don 1983) (Agency 1945) (Agency-Archives 1944), including the current Jewish Agency For Israel web page (Lambert 1974). These figures require future statistical attention, especially where it concerns Kolozsvar- with a census figure of 18,600 Jews. Nonetheless, it is evident that apostasy and conversion yielded much better survival rates. Our work seems to indicate that additional $9 \%$ of the actual number of Jews fitting into any of the census categories went undetected, hidden by undisclosed identities. (See Tables 3. and 4.)

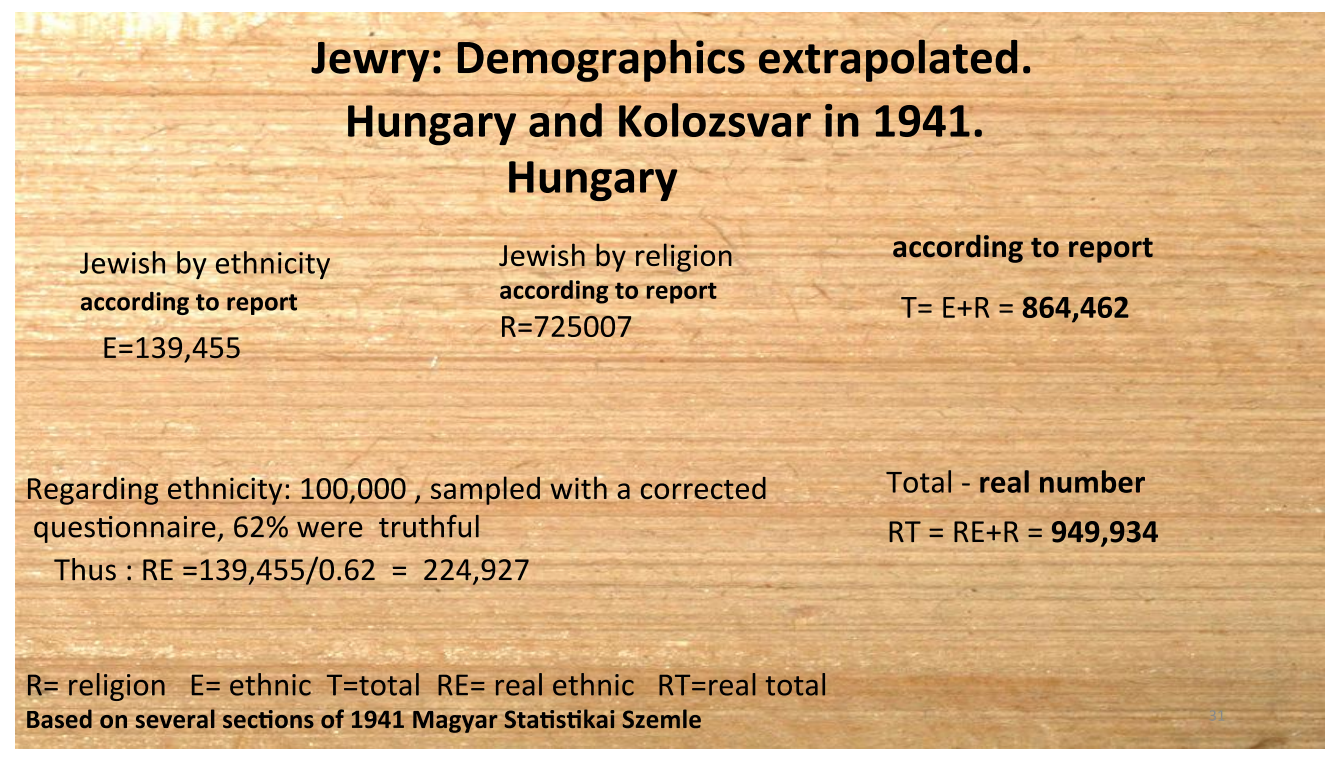

Table 3. (Tabulated by author) 


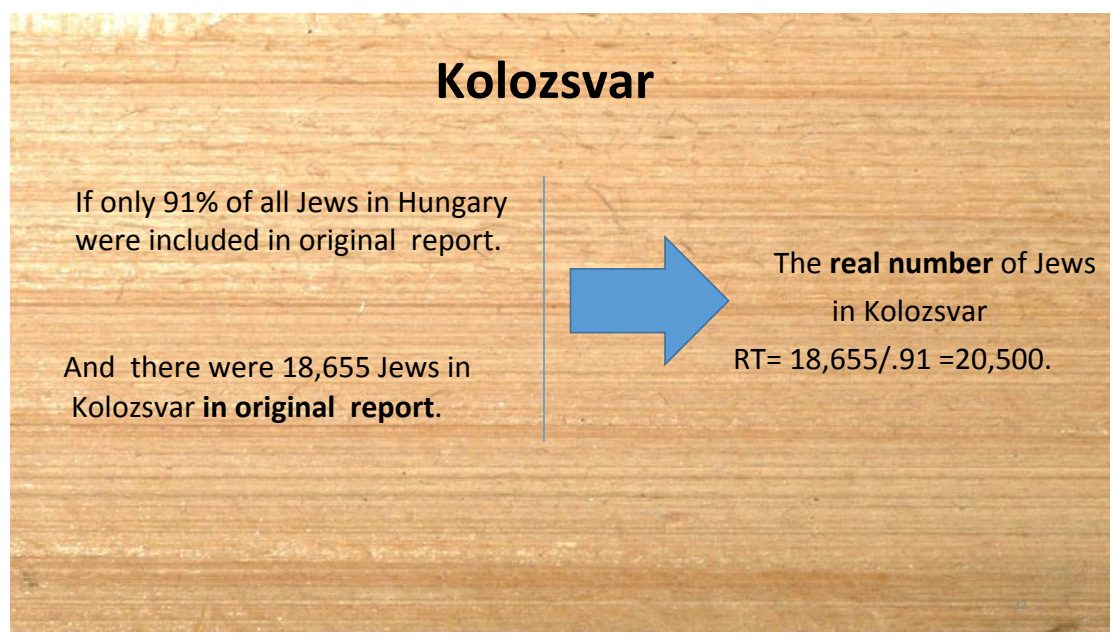

Table 4. (Tabulated by author)

\subsection{Hungarian Forced Labor}

"During the most dangerous time for the mass of Hungarian Jewry, in the spring and early summer of 1944, the Labor Service actually provided shelter"(Rozett 2013a, 274) The Hungarian Forced Labor System was intended to utilize every available Jewish man (and woman) for work exploitation and was later seen by the Nazis- as they demanded increasing numbers for their own usage- as a plausible alternative to extermination, at least for the time being. The first waves of recruits were men conscripted for the Hungarian army headed for Operation Barbarossa, as uniformed but unarmed members of the army and suffered horrendous mortality rates. As the war effort ground on increasing numbers were necessary for defensive works and additional numbers were called up, the age limits were increased and women were also added.(Rozett 2013a, 274) (Braham 1977, 943-1018) (Gidó 2010, 62-64) (Stark 2000). While the mortality rates in these battalions were horrendous, by the end of the war, those who survived, actually accounted for a significant survivor contingency from Transylvania- perhaps as many as several thousand- and, hence, Kolozsvar. These numbers are currently being analyzed and await publication.

\section{An Issue of Numbers}

While it may seem that post-war information should provide some clarifications, the facts become even further befuddled. Combined Soviet and Romanian troops entered the city on October $11^{\text {th }}, 1944$ (Rozett 2013b) and the first accounting of Jews in the city appear on November 20th, reported by the Jewish delegation to Northern Transylvania is listed as 1,500 (Case 2009, 190-195). Further population counts were maintained by the World Jewish Congress, on annual basis, and by 1947 the numbers rose to 7,355 (Stark 2000, 103) (Stark 2000). These numbers, however, account only for those who volunteered for identification, and the upheavals wrought by Soviet and Romanian forces in 1944, the divisiveness of territorial ambitions between Hungarians and Romanians, and the resurgence of antisemitism in 1946 (Gidó 2010), serve evidence that the figures are likely to be inaccurate. (Kovacs 1946) (Braham and Tibori Szabo 2007) (Szabo 2004). Indeed, currently circulating discussion of statistics are woefully inaccurate, not updated, considering how much new information is available, and not challenged when erroneously stated, even in scholarly literature bearing Braham's name (an example of very poor statistical data might be observed in Laszlo Varga, "The losses of Hungarian Jewry, a contribution to the statistical evidence (Braham 1990, 256-65))Thus, what happened in Kolozsvar in the spring of 1944 remains a continuing saga with further research needed in the future regarding these numbers, especially when considering the number of Jews who joined the ranks of the hidden and unaccounted.

Meaningful discussions in the future should also take into account our ability to join and unimpassioned narrative. What present day scholars need to understand is the element of the chronotope (Bhaktin 2002), when analyzing something, which took place at specific instance, now far in the distance. This type of approach might easily dispel some of the controversial issues raised by Arendt(Arendt 2006) and allow one to revisit historiography utilizing counterintuitive analysis as discussed by David Engel(Engel 2010) and examine the moment attempting a contemporaneous approach.

Furthermore, and of special note, are currently available documents, such as the World Jewish Congress, 1946 analysis of Transylvania, now located in the Zionist Archives in Jerusalem. One attempt at an analysis of this data was made in 2010, by Romanian researchers (Gidó 2010), but as admitted by the author (in print and in personal communications) this was only a partial analysis and there is further information to be obtained. Narrativization of these events, now extends into various disciplines, anthropology and sociology especially, and thus we cannot dismiss their input, even if controversial, as in the case of Bauman (Bauman 1989). Indeed, utilization of various perspectives may augment the 
real historiography of the time.

\section{Conclusion}

As has been amply pointed out, the various aspects of survival, even if analyzed in a methodic fashion, demonstrate a fragmented pattern. As far as Kolozsvar, the exact survival rates and the fate of some individuals, gets lost in the maelstrom of the Holocaust. However it is also likely that some people chose to become lost. Once the war was over, and faced with new turmoil, as the East and the West slugged it out for European hegemony, identity became a convenience for survival or advancement. For some, Communism offered a refuge, and they chose to part with their Jewish identity, while others, especially during the immediate period following the installation of Communism in Hungary and Romania, decided to emigrate, headed to Palestine, or fleeing the region to other locations. Thus revisiting the Holocaust in Koloszvar serves more than a scholarly exercise; it may shed light onto ongoing identity and personhood issues, and pose renewed significance for current generations of survivor offspring.

\section{References}

Agency, J. T. (1945). 600,000 of Hungary's 900,000 Jews Killed During Occupation, Swedish Diplomat Reports. JTA Archives.

Agency-Archives, J. T. (1944). "Jewish Leaders in England Urge Governmnet Action to Resuce Jews from Hungary. JTA Atchives, March 22,1944.

Arendt, H. (2006). Eichmann in Jerusalem : a report on the banality of evil, Penguin classics. New York, N.Y.: Penguin Books.

Bauer, Y. (1994). Jews for sale? : Nazi-Jewish negotiations, 1933-1945. New Haven: Yale University Press.

Bauman, Z. (1989). Modernity and the Holocaust. Ithaca, N.Y.: Cornell University Press.

Benshalom, R. (2001). We struggled for life : the Hungarian Zionist youth resistance during the Nazi Era. Jerusalem ; Hewlett, N.Y.: Gefen Pub. House.

Bhaktin, M. M. (2002). "Forms of Time and of the Chronotrope in the Novel:Notes toward a Historical Poetics". Edited by Brian Richardson, "Marrative Dynamics: Essays on time, plot,closure and frames: Ohio Stae University Press.

Braham, R. L. (1977). The Hungarian labor service system, 1939-1945, East European monographs. Boulder Colo. New York: East European quarterly; distributed by Columbia University Press.

Braham, R. L. (1981). The politics of genocide: the Holocaust in Hungary. 2 vols. Vol. 1. New York: Columbia University Press.

Braham, R. L. (1990). Studies on the Holocaust in Hungary. Boulder: Social Science Monographs and the Csengeri Institute for Holocaust Studies of the Graduate School and University Center of the City University of New York.

Braham, R. L. (1994). The politics of genocide : the Holocaust in Hungary. Rev. and enl. ed. 2 vols. Vol. 2, East European monographs. New York. Boulder: Rosenthal Institute for Holocaust Studies Social Science Monographs; Distributed by Columbia University Press.

Braham, R. L., \& Scott, M. (1998). United States Holocaust Memorial Museum. The Nazis' last victims : the Holocaust in Hungary. Detroit: Wayne State University Press.

Braham, R. L., \& Zolta n Tibori Szabo. (2007). A magyarországi holokauszt földrajzi enciklopédiája. Budapest: Park Könyvkiadó.

Carmilly, M. (1994). The road to life : the rescue operation of Jewish refugees on the Hungarian-Romanian border in Transylvania, 1936-1944, Bibliotheca Judaica. New York: Shengold.

Carmilly-Weinbereger, M. (1970). Memorial Volume for the Jews of Kolozsvar A Kolozsvari Zsidosag Emlekkonyve. New York: Shhulsinger Bros.

Case, H. (2009). Between states : the Transylvanian question and the European idea during World War II. Stanford, Calif.: Stanford University Press. http://dx.doi.org/10.11126/stanford/9780804759861.001.0001

Cohen, A. (1984). Continuity in the Change: Hungary, 19 March 1944. Jewish Social Studies, 131-144.

Cohen, A. (1986). The Halutz Resistance in Hungary, 1942-1944, East European monographs. Boulder Colo. New York: Social Science Monographs; Institute for Holocaust Studies of the City University of New York : Distributed by Columbia University Press.

Don, Y., \& George, M. (1983). The Demographic Development of Hungarian Jewry. Jewish Social Studies, 189-216.

Engel, D. (2010). Historians of the Jews and the Holocaust. Stanford, Calif.: Stanford University Press. 
Gidó, A., \& Sólyom, Z. (2010). The Surviving Jewish Inhabitants of Cluj, Carei and Oradea. The Survey of the World Jewish Congress in 1946. In Working Papers in Romanian Minority Studies. Cluj-Napoca: Romanian Institute for Research on National Minorities.

Herzberger, M. (2005). Survival. Austin, Texas: Groundbreaking Press.

Kovacs, J. (1946). Neo-Antisemitism in Hungary. Jewish Social Studies Published by: Indiana University Press, 8(3), 147-160.

Kübler-Ross, E. (1975). Death: the final stage of growth, Human development books. Englewood Cliffs, N.J.: Prentice-Hall.

Kübler-Ross, E. (1982). Living with death and dying. 1st Macmillan paperbacks ed. New York: Macmillan.

Lambert, G. (1974). Operation Hazalah. Indianapolis,: Bobbs-Merrill.

Lőwy, D., \& Dániel, L. (2005). A Kálváriától a tragédiáig : Kolozsvár zsidó lakosságának története. 2., jelentősen bőv.' es átdolg. kiad. ed. Kolozsvár: Koinónia.

Lőwy, D., \& Réka, S. (1998). A téglagyártól a tehervonatig : Kolozsvár zsidó lakosságának története. Kolozsvár: Erdélyi Szépmíves Céh.

Molnar, J. (2002). The Foundfation and Activities of the Hungarian Jewsih Council, March20-July7, 1944. Yad Vashem Studies XXX, 93-124.

Munkácsi, E. (1947). Hogyan történt? Adatok és okmányok a magyar zsidóság tragédiájához. Budapest,: Renaissance Kiadás.

Rozett, R. (2013a). Conscripted Slaves: Hungarian Jewish Forced Laborers on the Eastern Front during the Second World War. Jerusalem: Yad Vashem.

Rozett, R. (2013b). Coscripted Slaves. Jerusalem: Yad Vashem.

Stark, T. S. (2000). Hungarian Jews during the Holocaust and after the Second World War, 1939-1949 : a statistical review. Boulder: East European Monographs.

Szabo, Z. T. (2004). Transylvanian Jewry During the Postwar Period, 1945-48 (Part 1). East European Perspectives: October 1, 6(18).

Vago, B. (1966). The Destruction of the Jews Transylvania (Erdely Zsidosaganak Elpusztitasa). Edited by Randolp L. Braham, Hungarian-Jewish Studies. New York: World Federation of Hungarian Jews.

Vrba, R., \& Alan, B. (1964). I cannot forgive. New York: Grove Press.

\section{(cc) BY}

This work is licensed under a Creative Commons Attribution 3.0 License. 